\title{
Adoption of Dogs in the Czech Republic
}

\author{
D. NĚMCOVÁ ${ }^{1}$, P. NOVÁK ${ }^{2}$ \\ State Veterinary Administration, Brno, ${ }^{2}$ Department of Nutrition, and Zoohygiene, \\ Faculty of Veterinary Hygiene and Ecology, \\ University of Veterinary and Pharmaceutical Sciences, Brno, Czech Republic \\ Received December 16, 2002 \\ Accepted March 7, 2003
}

\begin{abstract}
Němcová D., P. Novák: Adoption of Dogs in the Czech Republic. Acta Vet. Brno 2003, 72: 421-427.

The aim of this work was to analyze selected factors playing a role in the adoption of dogs from shelters in the Czech Republic. The study was performed in two shelters from May to December 1999. Using a questionnaire, we obtained data about the adopted dogs (time spent in the shelter, age, sex and breed of the dog, dogs admitted to shelter by incoming category, group housing vs. individual housing), and demographic data about the new owners (age, sex, urban/rural housing type, previous experience with dogs, reason for the wish to own a dog, motivation for selecting a specific dog). We compared data about dogs adopted from shelter A situated in an urban environment with a population of 50 thousand, and from shelter B situated in a rural area, in a village with approximately 2000 inhabitants. Dogs in shelter A were most frequently brought in by the person who captured the animal $(41.3 \%)$, and surrendered by the owner $(28.0 \%)$. Dogs in shelter B in the rural area were most frequently delivered by municipal police $(82.0 \%)$. Before adoption, the dogs spent 53 days on average in shelter A, and 85 days in shelter B. The highest fractions of dogs adopted from both shelters were puppies 2-4-month-old $(26.7$ and $38.0 \%$, respectively), closely followed by dogs aged 8 months-to-2 years and 2-5 years. Sex did not play a significant role in dog adoption.

Among new owners adopting dogs from shelters A and B, those 26 to 60 years of age prevailed $\left(\chi^{2} 5.678, P<0.05 ; \chi^{2} 12.294, P<0.01\right.$, respectively) over those aged 18 to 26 years, and also over adopters older than 60 years $\left(\chi^{2} 26.329, P<0.01 ; \chi^{2} 13.677, P<0.01\right.$, respectively). No differences between adopters from the two shelters were found in reasons for adoption, except for personality of the dog that prevailed in shelter A $\left(\chi^{2} 4.285, P<0.05\right)$. Previous experience of $\operatorname{dog}$ ownership was reported by $96.0 \%$ new owners for shelter A, and $98.0 \%$ for shelter B. There were no differences found concerning the sex of new owners and presence of children in the family.

The findings from this pilot study indicate that adoption is more related to factors associated with the new owners than to factors associated with the dogs. The data may serve shelter personel and veterinarians to help develop strategies aimed at improving chances for adoption of dogs and shortening the time in shelter by providing detailed and qualified information to potential dog adopters.
\end{abstract}

Questionnaire, owners, dogs, age, sex, breed

Since prehistoric times people have acquired dogs for companionship and for work, but they have also abandoned them for various reasons. The last 40 years have seen a soaring growth in numbers of pet dogs in the USA (Arkow 1991) and also in Europe. Pet food industry products outsold baby food by a 4-to-1 ratio, amounting to $\$ 17$ billion at the beginning of the 1970s (A n on y mou s 1974). Expenditures for veterinary care of nearly 62 million dogs kept in the USA in 2001 alone increased from $\$ 4.5$ to 10.8 billion between 1991 and 2001 (AVMA 2002). The beneficial effects of dog and other pet ownership for human health have repeatedly been demonstrated (Beck 1992, 1996, 2000; Odendaal and Lehman 2000). However, there is a dark side to human and dog coexistence, namely, abandonment and relinquishment to shelters. Among the reasons for relinquishment of dogs to shelters are often unrealistic and/or anthropomorphic expectations of owners, and

Address for correspondence:

MVDr. Dita Němcová

SVS, Palackého 174

Czech Republic

Phone: +420 541594437

http://www.vfu.cz/acta-vet/actavet.htm 
behavioural problems, e.g. various forms of aggression such as interdog aggression leading to injuries mostly in young dogs (Baranyiová et al. 2003).

Control of stray dogs was reported as early as 1867 in New York (Arkow 1991), and the specific problem of pet overpopulation has been approached in the USA since the 1940s (Moulton et al. 1991), when the animal sheltering system began to grow as a consequence. Public shelters (animal control agencies) and private shelters (humane agencies) were involved in care and control of these animals. Care of stray, abandoned, surplus or unwanted animals has been carried out in many other countries. Shelters had been also established in Czechoslovakia, as indicated by the Report of the Society for the Protection of Animals located in Brno. In the "Report of Activities" carried out in 1936, need for a second shelter was mentioned because of increasing numbers of abandoned dogs (Slezák 1937). Municipal and District Veterinary Offices were responsible for care of these animals. However, in Czechoslovakia and later in the Czech Republic, larger numbers of animal shelters began to be established only after 1989. The underlying legislation was provided in the Veterinary Act No. 87/1987 Coll., Animal Protection Act No. 246/1992 Coll. (Dousek and Dousek 2002).

In the USA, more than 8 million dogs and cats are sheltered each year (Arkow 1994), and shelter euthanasia has been called the leading cause of death for dogs and cats $(\mathrm{O} 1 \mathrm{~s}$ on et al. 1991; 1993; B eck 1992). Estimated annual shelter animal intakes and euthanasia were $9 \%$ and 5\%, respectively, of the entire US dog population (Arkow 1994). In Great Britain, yearly more than 500 thousand surplus animals are abandoned, and in Scotland, $46 \%$ of healthy dogs were euthanized in veterinary clinics (Stead 1982). In Australia, the average age of dogs is only 3.5 years (Seksel 1997). Large numbers of dogs are euthanized only because of failed re-homing.

The estimated number of dogs living in the Czech Republic is about 1 million (Dou sek, personal communication). In 1998, about 50000 dogs were licensed in the capital, Prague. However, another estimated 100-150 thousand owned dogs were not registered with the respective municipal authorities. The shelter personnel in Prague-Troja estimated that at least 250 thousand dogs were kept in the capital. Thus with about 1.2 million people, some 150 to 300 thousand dogs were living in Prague in 1998 (Baranyiová et al. 1998a). The numbers for 2003 may be even higher. The numbers of dogs in other areas are only rough estimates. However, the numbers of sheltered dogs are increasing both in urban and rural areas; for example in shelter A in this study, the numbers of sheltered dogs between 1993 and 1998 increased more than fivefold. For the introduction of any community education programmes and efficient measures to decrease the numbers of unwanted and relinquished dogs, basic data are needed about the sheltered dogs along with demographic data about their adopters. The aim of our study, therefore, was to collect such pilot data and compare them with similar results in other countries in which the veterinary profession also has been dealing with the problem for several decades.

\section{Materials and Methods}

The study was carried out from May to December 1999 in two shelters in the Czech Republic. A total of 75 dogs from shelter A, and 50 dogs from shelter B was evaluated.

The shelters

Shelter A (capacity up to $50 \mathrm{dogs}$ ) is situated in an urban area with up to 50000 inhabitants. It was founded in 1992, and dogs from the entire county territory are admitted. Families adopting dogs from this shelter tend to live in a radius of about $50 \mathrm{~km}$. Visiting hours are six days per week, and the shelter is run by four employees. The local veterinarian is called in for routine procedures, for operations the dogs are transported to his office. The shelter also has a cat housing area (for about ten cats). Individual and group housing for dogs is provided. Quarantine capacity is $27 \%$ of the shelter housing capacity, and quarantine is 15 days.

Shelter B (capacity up to $100 \mathrm{dogs}$ ) is situated in a rural area, outside a village with up to 2000 inhabitants. The shelter was founded in 1996, and dogs from the entire county territory are admitted. Families adopting dogs from 
the shelter tend to live in a radius of about $50 \mathrm{~km}$. Visiting hours are five days per week; telephone arrangements may be made to visit at other times. The local veterinarian visits twice a week on a regular basis, and for operations or more complicated procedures the dogs are transported to his office. The shelter is for dogs exclusively. Both individual and group housing is available. Quarantine capacity is $10 \%$ of the shelter housing capacity, and quarantine is 14 days.

The questionnaire

The questionnaire was based on those by Mertens (1994) and Heidenberger (1994), and questions based on experience of personnel in both shelters under study were included.

The first part of the questionnaire included information about each dog as follows:

Part I - Dogs

Number of days in shelter

Age of the dog (2-4 months, 4-8 months, 8 months -2 years, 2-5 years, 5-8 years, 8 years).

Sex (male, female, neutered), breed (mixed breed, dog showing exterior signs of purebred animals)

Shelter housing type (individual, in group)

Incoming category (stray, surrender, other) including reasons for surrender, if known.

Part II - New owners

The second part of the questionnaire concerned the basic demographic data about the new owner and factors important for his/her selection of a specific dog, e.g. previous experience with dog ownership (Kidd et al. 1992a). Age (18-26, 26-60, 60 years)

Age categories are based on the assumption that the ages between 18 and 26 years is the period of study, preparation for job, housing acquisition, between 26-60 years is the productive age, and above 60 years is the retirement age.

Size of community (up to 2000, 2-10 000, 10-50 000, 50-100 000, and over 100000 inhabitants)

Sex (male, female)

Children in family (yes - no)

Previous experience with dog ownership (yes - no)

Reason for dog adoption (death of previous dog, feeling sorry for abandoned animals, loss of a dog, e.g. ran away, other)

Motivation to select a specific dog (size, appearance, age, personality, other). Personality of the dog is described as quiet, suitable for children; alert, suitable for guarding; friendly.

\section{Results and Discussion}

The results of the study are presented in Tables 1-3 with numbers of animals in individual and group housing given separately (Table 1). In recent years, there has been a definite trend to keep the dogs in groups instead of the traditional single housing. For example, by 1994, $51 \%$ of German shelters had group housing introduced. On average, $43 \%$ of individually kept dogs but $80 \%$ of group-housed dogs were socialized to a satisfying degree (Mertens 1994), and dogs from group housing were placed in a new home within 10.6 days whereas those from idividual housing spent 17.1 days before a new owner was found for them. In our pilot study with only two shelters involved, no such clear-cut data were obtained. The average time spent in shelter A was 43 days (individual housing), and 56 days (group housing), on average 53 days, in shelter B 117 days (individual housing), and 73 days (group housing), on average 85 days. In the study of Patronek et al. (1995), the average number of days spent in a shelter for purebred dogs 1 year of age was $4.27 \mathrm{~d}$, for mixed breed dogs of the same age $5.94 \mathrm{~d}$, for purebred dogs $\geq 1$ year, $5.92 \mathrm{~d}$, and for mixed breed dogs $\geq 1$ year 10.06 days. Moreover, in this study $72.5 \%$ of the dogs admitted to shelters were $\geq 1$ year, and $41 \%$ of the dogs were purebred. In another study (Wells et al. 2002) carried out in UK, dogs were kept in a rescue shelter from less than a month to more than 5 years.

The most frequently adopted dogs from both shelters were those aged 2-4 months (in shelter A, 26.7\%, and in shelter B, 38.0\%). All these puppies were housed in groups which was of paramount importance for their socialization. As for prognosis for the adoption success these young dogs had a fair chance to be well integrated into their new environment. According to Hart et al. (1998), puppies and kittens are generally preferred to adult dogs for adoption. Our results do not fully support this finding since similar numbers of older dogs 
Table 1

Characteristics of the adopted dogs (per cent, actual numbers in brackets)

\begin{tabular}{|c|c|c|c|c|c|c|c|}
\hline & \multicolumn{3}{|l|}{ Shelter A } & \multicolumn{3}{|l|}{ Shelter B } \\
\hline & & $\mathrm{I}$ & $\mathrm{G}$ & $\mathrm{T}$ & $\mathrm{I}$ & $\mathrm{G}$ & $\mathrm{T}$ \\
\hline \multirow{7}{*}{ 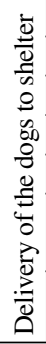 } & Municipal police & $2.7(2)$ & $1.3(1)$ & $4.0(3)$ & $22.0(11)$ & $60.0(30)$ & $82.0(41)$ \\
\hline & Born in shelter & $0.0(0)$ & $9.3(7)$ & $9.3(7)$ & $0.0(0)$ & $4.0(2)$ & $4.0(2)$ \\
\hline & Brought in by finder & $10.7(8)$ & $30.7(23)$ & $41.3(31)$ & $4.0(2)$ & $6.0(3)$ & $10.0(5)$ \\
\hline & Caught by shelter personnel & $4.0(3)$ & $6.7(5)$ & $10.7(8)$ & $0.0(0)$ & $0.0(0)$ & $0.0(0)$ \\
\hline & Surrendered by previous owner & $8.0(6)$ & $20.0(15)$ & $28.0(21)$ & $0.0(0)$ & $0.0(0)$ & $0.0(0)$ \\
\hline & $\begin{array}{l}\text { Taken away from previous } \\
\text { owner for cruelty }\end{array}$ & $0.0(0)$ & $4.0(3)$ & $4.0(3)$ & $0.0(0)$ & $0.0(0)$ & $0.0(0)$ \\
\hline & $\begin{array}{l}\text { Taken away - death } \\
\text { of previous owner }\end{array}$ & $0.0(0)$ & $2.7(2)$ & $2.7(2)$ & $2.0(1)$ & $2.0(1)$ & $4.0(2)$ \\
\hline \multicolumn{2}{|c|}{ Average time in shelter (days) } & 43 & 56 & 53 & 117 & 73 & 85 \\
\hline \multirow{6}{*}{$\begin{array}{l}00 \\
0 \\
0 \\
0 \\
0 \\
0 \\
0 \\
0 \\
\end{array}$} & 2-4 months & $0.0(0)$ & $26.7(20)$ & $26.7(20)$ & $0.0(0)$ & $38.0(19)$ & $38.0(19)$ \\
\hline & 4-8 months & $1.3(1)$ & $10.7(8)$ & $12.0(9)$ & $0.0(0)$ & $8.0(4)$ & $8.0(4)$ \\
\hline & 8 months -2 years & $10.7(8)$ & $13.3(10)$ & $24.0(18)$ & $18.0(9)$ & $10.0(5)$ & $28.0(14)$ \\
\hline & $2-5$ years & $10.7(8)$ & $14.7(11)$ & $25.3(19)$ & $8.0(4)$ & $16.0(8)$ & $24.0(12)$ \\
\hline & $5-8$ years & $4.0(2)$ & $8.0(6)$ & $10.7(8)$ & $2.0(1)$ & $0.0(0)$ & $2.0(1)$ \\
\hline & Above 8 years & $0.0(0)$ & $1.3(1)$ & $1.3(1)$ & $0.0(0)$ & $0.0(0)$ & $0.0(0)$ \\
\hline \multirow{2}{*}{ હ } & Male & $18.7(14)$ & $36.0(27)$ & $54.7(41)$ & $14.0(7)$ & $40.0(20)$ & $54.0(27)$ \\
\hline & Female & $6.6(5)$ & $38.7(29)$ & $45.3(34)$ & $14.0(7)$ & $32.0(16)$ & $46.0(23)$ \\
\hline \multirow{2}{*}{ 总 } & Signs of a specific breed & $17.3(13)$ & $6.7(5)$ & $24.0(18)$ & $18.0(9)$ & $8.0(4)$ & $26.0(13)$ \\
\hline & Mixed breed & $8.0(6)$ & $68.0(51)$ & $76.0(57)$ & $10.0(5)$ & $64.0(32)$ & $74.0(37)$ \\
\hline
\end{tabular}

Explanation: I - Individual housing, G - Group housing, T - Total

were adopted except for the categories of 4-8 months and over 5 years of age. Dogs from both individual and group housing were adopted with no differences in frequency. The age of the dog at adoption was important for the new owners only as the fourth ranked criterion for shelter A, and as the third criterion for shelter B.

There was practically no difference between male (A, 54.7\%, B 54.0\%) and female dogs adopted in both shelters. Although males from group housing in both shelters were slightly more likely to be adopted, no significant differences between group and individual housing were found. No neutered animals were reported in an earlier study on sex differences in behaviour of dogs in the Czech Republic (Baranyiová et al. 1998b) and the same was true in this study; male neutering rate is extremely low in this country similar to the report for Japan (Hart et al. 1998).

Mixed breed dogs were sheltered and also adopted more often (shelter A, 76.0\%, shelter B , 74.0\%) than dogs with exterior signs of a specific breed. Mixed breed dogs that were adopted were kept in group housing more often than "purebreds" ( shelter A, $\chi^{2}=27.528$, $P<0.01$; shelter B $\left.\chi^{2}=14.814, P<0.01\right)$.

In our study, most dogs were brought to shelter A by the person who found it (41.3\%), or were surrendered by the owner $(28.0 \%)$. In shelter B, most dogs were brought in by municipal police (82.0). In a similar study carried out in Japan (Hart et al. 1998), 61.0\% dogs were caught as stray by shelter personnel.

The reasons for relinquishment of dogs to shelters, as indicated by their owners, were moving (4), small apartment (3), lack of time for the dog (2), financial problems (2), the dog does not catch mice (1), dog being too large (1), dog not allowed in cooperative housing (1), dog aggressive toward children (1), escaping dog (1), no reason specified (5). Thus 
behavioural problems accounted for only $9.5 \%$ of relinquishments. In the study of DiGiacomo et al. (1998), behavioral problems accounted for $26.4 \%$ of relinquishment, but these were less prominent as contributing factors than other factors.

Table 2

Characteristics of the adopter - basic data (\%, actual number in brackets)

\begin{tabular}{|l|l|l|l|l|l|l|l|l|l|l|l|l|}
\hline Shelter & \multicolumn{3}{l|}{$\begin{array}{l}\text { Age of adopter } \\
\text { (years) }\end{array}$} & \multicolumn{2}{l|}{$\begin{array}{l}\text { Community size } \\
\text { (thousands of inhabitants) }\end{array}$} & \multicolumn{2}{l|}{ Children } & \multicolumn{2}{l|}{ Sex } \\
\hline & $18-26$ & $26-60$ & $\begin{array}{l}\text { above } \\
60\end{array}$ & up to 2 & $2-10$ & $10-50$ & $50-100$ & $\begin{array}{l}\text { above } \\
100\end{array}$ & yes & no & Male & Female \\
& & & & & & & & & & \\
\hline A & 30.7 & 62.7 & 6.7 & 45.3 & 9.3 & 29.3 & 6.7 & 9.3 & 44.0 & 56.0 & 48.0 & 52.0 \\
& $(23)$ & $(47)$ & $(5)$ & $(34)$ & $(7)$ & $(22)$ & $(7)$ & $(7)$ & $(33)$ & $(42)$ & $(36)$ & $(39)$ \\
\hline B & 16.0 & 70.0 & 14.0 & 42.0 & 28.0 & 8.0 & 0.0 & 22.0 & 44.0 & 56.0 & 58.0 & 42.0 \\
& $(8)$ & $(35)$ & $(7)$ & $(21)$ & $(14)$ & $(4)$ & $(0)$ & $(11)$ & $(22)$ & $(28)$ & $(29)$ & $(21)$ \\
\hline
\end{tabular}

In our study, the adopters were mostly 26-60 years of age (shelter A, $62.7 \%$, shelter B, $70.0 \%$ ), i.e. belonging to the productive population with financial means and stabilized conditions for keeping a dog (see Table 2). As reported by shelter personnel, the age group between 18 and 26 years seemed to face problems with living quarters, studies, separation from the dog when traveling etc., and in the group of age 60 and beyond, the risk of disease, connected with possible hospitalization of the owners was a factor in decisions concerning the adoption of a specific dog. Most new owners in our study (shelters A and B, 45.3\%, and $42.0 \%$, respectively) were living in rural areas, in villages with up to 2000 inhabitants. Numbers of men and women acquiring dogs from the shelters under study were equal, and in $44 \%$ of the dog-adopting families there were children. This finding is in agreement with that of Baranyiová et al. (1998a) who found that children are in more than half of dogowning Czech families that participated in their questionnaire study. Previous experience with dog ownership was reported by $96.0 \%$ new owners (shelter A), and by $98.0 \%$ (shelter B). This experience may be a good predictor of a successful adoption, since Kidd et al. (1992a) found that adopters with experience in dog ownership retained significantly more newly adopted pets than those who never had pets.

Our study further showed that selection of a specific dog was most influenced by the appearance of the animal (shelter A 34.7\%, shelter B 34.0\%). Second most important criterion was personality of the $\operatorname{dog}$ (shelter A, 25.3\%), and its size (shelter B, 26.0\%). Third most important aspect was the size of the dog in shelter A (21.3\%), and its age in shelter B (22.0\%). However, these differences were not significant. Authors who analyzed factors important for successful dog adoption (Posage et al. 1998), found that terrier, hound, toy and nonsporting breeds were significantly associated with successful adoption. Furthermore, the size, coat colour (preferred golden, grey and white) along with the history of an indoor environment were significant predictors of successful adoption.

Among reasons for adoption, new owners reported most frequently death of their previous dog, feeling sorry for the sheltered dogs, other loss of their pet (e.g. ran away), other reasons such as companion for children and for other pets, contact with animals etc. (see Table 3).

Our pilot data, the first reported for this country, have shown that among factors playing a role in successful adoption were the size and appearance of the dog, its personality and, less importantly, age. Puppies aged 2-4 months dogs of mixed breeds were most likely to be adopted. Adopters were most frequently people in economically productive age group (i.e., between 26-60 years), and 97\% of them had had previous experience with dog ownership. Adoption thus related also to factors associated with the new owners. Our study, however, does not provide data on the outcome of these adoptions. 
Table 3

Adopter - other data (values in \%, actual numbers in brackets)

\begin{tabular}{|c|c|c|c|c|c|c|c|c|c|c|c|}
\hline \multirow[t]{2}{*}{ Shelter } & \multicolumn{2}{|c|}{$\begin{array}{l}\text { Previous } \\
\text { experience } \\
\text { with dogs } \\
\text { ownership }\end{array}$} & \multicolumn{4}{|c|}{$\begin{array}{l}\text { Reason } \\
\text { for dog adoption }\end{array}$} & \multicolumn{5}{|c|}{$\begin{array}{l}\text { Motivation } \\
\text { for dog selection }\end{array}$} \\
\hline & Yes & No & $\begin{array}{l}\text { Death } \\
\text { of dog }\end{array}$ & $\begin{array}{l}\text { Feeling } \\
\text { sorry }\end{array}$ & $\begin{array}{l}\text { Other } \\
\text { loss } \\
\text { of dog }\end{array}$ & Other & Size & $\begin{array}{l}\text { Appea- } \\
\text { rance }\end{array}$ & Age & $\begin{array}{l}\text { Perso- } \\
\text { nality } \\
\text { of dog }\end{array}$ & Other \\
\hline $\mathrm{A}$ & $\begin{array}{l}96.0 \\
(72)\end{array}$ & $\begin{array}{l}4.0 \\
(3)\end{array}$ & $\begin{array}{l}42.7 \\
(32)\end{array}$ & $\begin{array}{l}42.7 \\
(32)\end{array}$ & $\begin{array}{l}6.7 \\
(5)\end{array}$ & $\begin{array}{l}8.0 \\
(6)\end{array}$ & $\begin{array}{l}21.3 \\
(16)\end{array}$ & $\begin{array}{l}34.7 \\
(26)\end{array}$ & $\begin{array}{l}14.7 \\
(11)\end{array}$ & $\begin{array}{l}25.3 \\
(19)\end{array}$ & $\begin{array}{l}4.0 \\
(3)\end{array}$ \\
\hline B & $\begin{array}{l}98.0 \\
(49)\end{array}$ & $\begin{array}{l}2.0 \\
(1)\end{array}$ & $\begin{array}{l}36.0 \\
(18)\end{array}$ & $\begin{array}{l}20.0 \\
(10)\end{array}$ & $\begin{array}{l}32.0 \\
(16)\end{array}$ & $\begin{array}{l}12.0 \\
(6)\end{array}$ & $\begin{array}{l}26.0 \\
(13)\end{array}$ & $\begin{array}{l}34.0 \\
(17)\end{array}$ & $\begin{array}{l}22.0 \\
(11)\end{array}$ & $\begin{array}{l}8.0 \\
(4)\end{array}$ & $\begin{array}{l}10.0 \\
(5)\end{array}$ \\
\hline
\end{tabular}

To increase chances of adoption for sheltered dogs and, if possible, shorten their time spent in shelters, a good collaboration and joint effort of shelter personnel and veterinarians is advisable, since Kidd et al. (1992b) have shown that veterinarian's clients rejected significantly fewer pets and had fewer unreasonable expectations for pets' roles in their own and their children's lives than did humane society adopters. Emphasis should also be put on training of shelter personnel who should be able to assess the suitability of incoming dogs for group/individual housing and promote socialization of dogs in group housing. Qualified information and advice in selecting a suitable animal matching the expectations and situation of adopters, may help to reduce the numbers of sheltered dogs. A thorough collection of data on dogs and their potential new owners as well as follow up on the success of adoption is desirable. Moreover, the general public should be made aware of all problems connected with irresponsible dog ownership, the importance of dog spay/neuter programmes as carried out in many countries. Such concerted activities should result in fewer abandoned and unwanted animals and their relinquishment to shelters.

\section{Adopce psů z útulků v České republice}

Cílem práce bylo zjistit, které faktory nejvíce ovlivňují adopci psů z útulků v České republice. Pomocí dotazníků jsme ve dvou útulcích v období od května do prosince 1999 získávali základní údaje o adoptovaných psech (délka pobytu psa v útulku, věk a pohlaví psa, plemeno a způsoby jeho předání do útulku), a o jejich nových majitelích (věk, bydliště, pohlaví, předchozí zkušenosti s chovem psa, důvod převzetí psa z útulku a motivace výběru konkrétního psa). Srovnávali jsme údaje o psech, kteří byli adoptováni z útulku $\mathrm{A}$, situovaného $\mathrm{v}$ centru městské aglomerace do 50 tisíc obyvatel, a z útulku $\mathrm{B}$, který byl v rurální oblasti, v obci do 2 tisíc obyvatel. Do útulku A umístěného ve městě, byli psi nejčastěji předáni nálezcem (41,3\%), a vlastním majitelem $(28,0 \%)$. Do útulku $\mathrm{B}$, tedy v rurální oblasti, psy přivážela nejčastěji městská policie $(82,0 \%)$. Před převzetím novými majiteli ztrávili psi v útulku A v průměru 53 dny, v útulku B 85 dnů.

V obou sledovaných skupinách byli noví majitelé častěji ve věku 26-60 let než 18-26 let $\left(\chi^{2} 5,678, P<0.05 ; \chi^{2} 12.294, P<0.01\right)$, a častěji než ve věku nad 60 let $\left(\chi^{2} 26.329, P<0.01\right.$; $\left.\chi^{2} 13.677, P<0.01\right)$. V motivacích pro adopci psa nebyly nalezeny významné rozdíly až na povahu psa v útulku A $\left(\chi^{2} 4,285, P<0.05\right)$. Zkušenosti s chovem psa mělo v útulku A 96,0 $\%$ a v útulku B 98,0 \% nových majitelů. Získané údaje ukazují, že pro adopci psů jsou významnější faktory spojené s novými nabyvateli než faktory spojené se samotnými psy. Personál útulku i veterináři mohou společně připravit strategii cílenou na zkrácení pobytu psů v útulku i zlepšování jejich šancí k převzetí. 


\section{Acknowledgement}

Thanks are extended to E. Baranyiová for helpful suggestions and critical reading of the manuscript.

\section{References}

ANONYMOUS 1974: The pet set: chic unleashed. Newsweek, September 9, p. 74-78

ARKOW, P 1991: Animal control laws and enforcements, JAVMA 198:1164-1172

ARKOW, P 1994: A new look at animal "overpopulation“. Anthrozoos 7: 202-205

AVMA Pet Ownership report 2002

BARANYIOVÁ, E, HOLUB, A, ERNSTOVÁ, M 1998a: Pes v České republice. In Czech (Dogs in the Czech Republic), Proceedings „Ochrana zvířat a welfare“, pp. 11-12

BARANYIOVÁ, E, HOLUB, A, JANÁČKOVÁ, B 1998b: Pohlavní rozdíly v chování psů v českých domácnostech. In Czech. (Sex differences in behaviour of dogs in Czech households). Proceedings „Ochrana zvírat a welfare“, pp. 16-17

BARANYIOVÁ, E, HOLUB, A, MARTINÍKOVÁ, M, NEČAS, A, ZATLOUKAL, J 2003: Epidemiology of intraspecies bite wounds in dogs in the Czech Republic. Acta Vet Brno 72: 55-62

BECK, AM 1992: Health and behavioral implications of pet ownership. In: Behavioral Problems in Small Animals. Purina Specialty Review, Pro Visions, pp. 4-12

BECK, AM, KATCHER, AH 1996: Between Pets and People, The Importance of Animal Companionship. Purdue University Press, West Lafayette, Indiana, $316 \mathrm{p}$

BECK, AM 2000: The Human-Dog Relationship: a Tale of Two Species. In: Macpherson CNL, Meslin, FX, Wandeler, AI (Eds): Dogs. Zoonoses and Public Health, CABI Publishing, Wallingford, pp. 1-16

DIGIACOMO, N, ARLUKE, A, PATRONEK, GJ, 1998: Surrendering pets to shelters: the relinquisher's perspective. Anthrozoos 11: 41-51

DOUSEK, J 1998: personal communication

DOUSEK, J, DOUSEK, J. Jr. 2002: Pes v zrcadle předpisů. Praha, ORAC, vyd. 1., pp. 10-38

HART, LA, TAKAYANAGI, T, YAMAGUCHI, H 1998: Dog and cats in animal shelters in Japan. Anthrozoos 11: $157-163$

HEIDENBERGER, E 1994: Resozialisierung von Zwingerhunden aus Einzelhaltung. Tierärztl. Umschau 49: 431439

KIDD, AH, KIDD, RM, GEORGE, CC 1992a: Successful and unsuccessful pet adoptions. Psychological Reports 70: $547-561$

KIDD, AH, KIDD, RM, GEORGE, CC 1992b: Veterinarians and successful pet adoptions. Psychological Reports 71: 551-557

MERTENS, P 1994: Die Haltung von Hunden in Tierheim - Verhaltens- und tierschutzrelevante Aspekte der Einzel- und Gruppenhaltung, Dissertation, pp. 99-125

MOULTON, C, WRIGHT, P, RINDY, K 1991: The role of animal shelters in controlling pet overpopulation: JAVMA, Vol 198, No 7, pp. 1172-1176

ODENDAAL, JSJ, LEHMAN, SMC 2000: The role of phenylethylamine during positive human-dog interactions. Acta Vet Brno 69: 183-188

OLSON, P, MOULTON, C, NETT, T, SALMON, M 1991: Pet overpopulation: A challenge for companion animal veterinarians in the 1990s. JAVMA 198: 1151-1152

OLSON, PN, MOULTON, C 1993: Pet (dog and cat) overpopulation in the United States. J Reprod Fertil 47: 433438

PATRONEK, GJ, GLICKMAN, LT, MOYER, MR 1995: Population dynamics and the risk of euthanasia for dogs in an animal shelter. Anthrozoos 8: $31-43$

POSAGE, JM, BARTLETT, PC, THOMAS, DK 1998: Determining factors for successful adoption of dogs from an animal shelter. J Am Vet Med Assoc 213: 478-482

SEKSEL K 1997: Puppy socialization classes. Progress in Companion Animal Behavior. Vet Clin N Am 27: $465-$ 477

SLEZÁK, K 1937: Jednatelská zpráva za rok 1936 Spolku na ochranu zvířat se sídlem v Brně, 15 p.

STEAD, AC 1982: Euthanasia in the dog and cat. J. Small Anim Pract 23: 37-43

WELLS, DL, GRAHAM, L, HEPPER, PG 2002: The influence of length of time in a rescue shelter on the behaviour of kennelled dogs. Animal Welfare 11: 317-325 